\title{
Physicochemical Properties of Alkaline Serine Proteases in Alcohol
}

\author{
Shui-Tein Chen, ${ }^{1,4}$ Shiah-Yun Chen, ${ }^{1}$ Chen-Chen Tu, ${ }^{2}$ Shyh-Horng Chiou, ${ }^{1,2}$ and Kung- \\ Tsung Wang, ${ }^{1,3}$
}

Received December 28, 1994

The alkaline proteases subtilisin Carlsberg and alcalase possess substantial enzymatic
activity even when dissolved in ethanol. The crude enzymes were purified by gel filtration
and the main fractions suspended in ethanol to give a translucent suspension. Both the
supernatant and the resuspended precipitate after high-speed centrifugation were found to
have enzymatic activities. The solubility of subtilisin Carlsberg in anhydrous ethanol was
found to be $45.1 \mu \mathrm{g} / \mathrm{ml}$ and that of alcalase was $48.1 \mu \mathrm{g} / \mathrm{ml}$ by Coomassie blue dye-binding
method using bovine serum albumin as a standard. In the presence of water, the solubility
of both enzymes increased with water content. The stability of enzymes incubated in
ethanol was assayed by their amidase and transesterase activities using Ala-Ala-Pro-Phe-
pNA as substrate in phosphate buffer ( $\mathrm{pH} 8.2$ and Moz-Leu-OBzl as substrate in
anhydrous ethanol, respectively. The soluble enzymes have a half-life of about $36 \mathrm{hr}$ and
that of suspended enzymes about $50 \mathrm{hr}$ in the amidase activity assay, whereas the same
soluble enzymes have a half-life of about several hours and that of suspended enzymes $1 \mathrm{~h}$
by the transesterase activity assay. The stability of both enzymes decreased as water
concentration increased. The diastereoselectivity of the enzyme-catalyzed hydrolysis of
diastereo pairs of tetrapeptide esters, L-Ala-L-Ala-(D- or L-)Pro-L-Phe-OMe and $\mathrm{L}-\mathrm{Ala}-\mathrm{L}-$
Ala-(D- or L-)Ala-L-Phe-OMe, in phosphate is as high as that of the transesterification of
these substrates in ethanol. It is concluded that active sites and selectivity of alkaline serine
proteases in anhydrous alcohol are probably very similar to those in aqueous solution in
spite of the fact that a lower reactivity is usually associated with the enzymes in
nonaqueous solvents.

KEY WORDS: Alkaline proteases; subtilisin Carlsberg; alcalase; amidase; transesterase; nonaqueous catalysis.

\section{INTRODUCTION}

The search for proteases that are stable in organic solutions for peptide synthesis and biocatalysis application has been extensive recently (Waks, 1986; Klibanov, 1986; Brink et al., 1988; Khmelnitsky et al., 1988; Riva et al., 1988; Schellenberger

\footnotetext{
${ }^{1}$ Institute of Biological Chemistry, P.O. Box 23-106, Academia Sinica, Taipei, Taiwan.

${ }^{2}$ Institute of Biochemical Sciences, National Taiwan University, Taipei, Taiwan.

${ }^{3}$ Department of Chemistry, National Taiwan University, Taipei, Taiwan.

${ }^{4}$ To whom correspondence should be addressed.
}

and Jakubke, 1991; Erp et al., 1991; Gupta, 1992; Dordick, 1992). Several studies have demonstrated that it is possible to use proteases to catalyze peptide synthesis in organic solvents (West and Wong, 1986; Ricca and Crout, 1989; Chen et al., 1992a,b; Gill and Vulfson, 1993). Some enzymes can maintain selectivities in organic solvents and others cannot (Matsushima et al., 1984; Margolin et al., 1987; Sakurai et al., 1988; Stahl et al., 1990; Fitzpatrick and Klibanov, 1991; Chen et al., 1991a,b, 1992a,b; Khan et al., 1992).

Alcalase is an endoprotease of the serine type, which was prepared from a selective strain of 
Bacillus licheniformis. The major enzyme component in commercial preparation of alcalase is reported to be the subtilisin Carlsberg (alkaline protease $\mathrm{A}$ ), a serine protease, which is one of the most thoroughly characterized bacterial proteases (Philipp and Bender, 1983). Alcalase is widely used as a detergent additive and as a digesting enzyme. Subtilisin Carlsberg is easily purified from the fermentation of a microorganism of selected Bacillus strain and commercially available as a relatively abundant enzyme preparation. Both preparations of subtilisin Carlsberg and alcalase have been used as catalysts for peptide bond formation in organic solvents (Chen et al., 1991a, 1992a) and for resolution of racemic amino acids (Chen et al., 1992b). The subtilisin Carlsberg has also been used as a heterogeneous biocatalyst in organic synthesis (Margolin et al., 1987; Riva et al., 1988).

The alcalase is currently supplied as a brown liquid and the water content can be removed from the enzyme solution by repeated washing with anhydrous alcohol. Early reports indicated that some proteins could be solubilized in an apolar solvent in the presence of surfactants. However, there have been no reports on studies regarding the solubility behavior of proteolytic enzymes in organic solvents. Much is understood about the kinetic properties and active-site conformation of Bacillus subtilisins (Wells and Estell, 1988). We have found the alkaline serine proteases, i.e., alcalase and subtilisin Carlsberg, can dissolve in anhydrous ethanol and maintain activity (Chen $e t$ $a l ., 1993 a, 1993 b)$. In this report we further characterize the physicochemical properties with regard to the solubility, stability, reactivity, selectivity, and water contents of the dissolved and suspended enzymes in ethanol and the active-site structure of these alkaline proteases in anhydrous alcohol as compared with those in aqueous solution.

\section{MATERIALS AND METHODS}

Alcalase was purchased from Novo Industries (Copenhagen, Denmark) as a brown liquid with a specific activity of $2.5 \mathrm{AU}$ (Anson units) $/ \mathrm{ml}^{5}$

\footnotetext{
${ }^{5}$ Abbreviations: AU, Anson units; Moz, methoxybenzyloxycarbonyl; pNA, $p$-Nitroanilide; OBzl, benzyl ester; OMe, methyl ester; Suc, succinyl; HoBt, N-hydroxybenzotriazo.
}

Subtilisin Carlsberg (protease type VIII, $11.6 \mathrm{units} / \mathrm{mg}$ ) and amino acids were purchased from Sigma Chemical (St. Louis, MO). L-Amino acids were used except those specified for D- or racemic amino acids. The proteolytic activities of alcalase and subtilisin Carlsberg were determined spectrophotometrically using hemoglobin as substrate and found to be $2.37 \mathrm{AU} / \mathrm{ml}$ for alcalase and 11.96 units/mg for subtilisin Carlsberg, Thionyl chloride was purchased from E. Merck (Darmstadt, Germany). The peptide substrates were prepared by the established method. Optical rotation was measured on a Universal Polarimeter (Schmidt \& Haensch, Berlin, Germany). NMR was taken on a Bruker AM-400 and chemical shifts of ${ }^{1} \mathrm{H}$ NMR spectra were reported relative to reference solvent peaks. Kinetic data were measured on a Hitachi U-2000 spectrophotometer (Tokyo, Japan). HPLC was run on a Hitachi liquid chromatograph with an adjustable pump and a variable UV detector, and data were collected on a Hewlett-Packard HP 3394A Integrator (Palo Alto, CA). Water content was determined on a Shimadzu GC 3 model (Tokyo, Japan) with a Polarpark $\mathrm{Q}$ column (Hewlett-Packard, Palo Alto, CA) and a thermoconductivity detector. Enzyme-bound water was also determined by the Karl Fischer titration method using a Metrohm 684 KF coulometer (Herisau, Switzerland). A Suntex P.C. 303 auto-pH controller was used (Suntex Instruments, Taipei, Taiwan) to maintain constant $p H$. Thin-layer chromatography (TLC) was performed on precoated plates of silica-gel G (E. Merck). Methanol, ethyl acetate, methylene chloride, dioxane, ether, and acetone (HPLC and reagent grade) were obtained from ALPS Chemical (Hsinchu, Taiwan).

\subsection{Removal of Water from the Alcalase or Subtilisin Carlsberg Solution}

Alcalase $(1.0 \mathrm{ml})$ and anhydrous ethanol $(10 \mathrm{ml})$ were added to a centrifuge tube $(20 \mathrm{ml})$ and the mixture was agitated on a supermixer for 10 min. The resulting mixture was centrifuged $(5000 \mathrm{rpm})$ for $10 \mathrm{~min}$ to spin down the enzyme, and the supernatant was decanted. Ethanol $(10 \mathrm{ml})$ was added again, and the same procedure was repeated three times until water was removed completely. Subtilisin Carlberg was treated similarly as above. 


\subsection{Enzyme Assays}

The proteolytic activities of alcalase and subtilisin Carlsberg were assayed spectrophotometrically by measuring the absorbance increase at $500 \mathrm{~nm}$ by Folin-Ciocalteu's phenol reagent due to the release of trichloroacetic acid-soluble products from the hydrolysis of globin chains. The assays were performed at $p \mathrm{H} 7.5$ at $37^{\circ} \mathrm{C}$ in phosphate buffer. According to the information supplied from Novo, $1 \mathrm{AU}$ is the amount of enzyme which under standard conditions digests globin chains at an initial rate by liberating the same amount of TCA-soluble product per $\min$ as 1 mequiv of tyrosine (again measured by Folin-Ciocalteu's phenol reagent). Thus $1 \mathrm{AU}=1000 \mathrm{U}$, and $1 \mathrm{U}=$ $1 \mathrm{mmol}$ of L-Tyr-OMe hydrolyzed per min.

Transesterification activity was measured by mixing Moz-Leu-OBzl $(0.25 \mathrm{mmol}, 114 \mathrm{mg})$ and absolute ethanol $(5 \mathrm{ml})$, to which was added alcalase $(100 \mu \mathrm{l}$, prewashed with ethanol three times) or subtilisin Carlsberg $(100 \mu \mathrm{g})$. The resulting solution was stirred at room temperature for $25 \mathrm{~min}$ and the reaction was quenched by the addition of enough $\mathrm{HCl}(0.10 \mathrm{M}, 4.8-4.9 \mathrm{ml})$ to make a final volume of $10 \mathrm{ml}$. The solution was centrifuged for $5 \mathrm{~min}$ at $3000 \mathrm{rpm}$, and aliquots $(20 \mu 1)$ of the supernatant were analyzed by HPLC using an RP-18 column and detected by UV measurement at $254 \mathrm{~nm}$ using $15 \%(\mathrm{v} / \mathrm{v})$ acetonitrile as the eluent. The peak area corresponding to Moz-Leu-OEt was measured, and the reaction rates of transesterification were estimated by comparison of each measured area with the calibration curve using Moz-Leu-OEt as standards.

\subsection{Solubility of the Enzymes in Ethanol}

The solubility of the enzymes in anhydrous ethanol and in ethanol containing $1-10 \%$ of water was measured by the Coomassie blue dye-binding method using BSA as a calibration standard. Coomassie brilliant blue $\mathrm{G} 250(50 \mathrm{mg})$ dissolved in ethanol $(25 \mathrm{ml})$ was added to phosphoric acid $(50 \mathrm{ml})$ and diluted to a final volume of $500 \mathrm{ml}$ with distilled water. The resulting solution was filtered and stored until further use. BSA solutions in a concentration range of $0.02-0.3 \%$ were used as calibration standards. Aliquots $(0.1 \mathrm{ml})$ of each supernatant of the enzyme dissolved in ethanol were reacted with the dye and absorbance measurements at $595 \mathrm{~nm}$ of each solution compared with the standard curve in order to estimate the concentrations of enzymes in ethanol.

\subsection{Water Content of the Enzymes in Anhydrous Ethanol}

The unremovable water that bound strongly with the enzyme in alcoholic solution was measured by the Karl Fischer titrimetric method and a gas chromatography (GC) method using a thermoconductivity detector. Anhydrous ethanol containing $0.01-0.05 \%$ of water $(100 \mu \mathrm{l})$ was injected into the GC to obtain a standard curve for water determination. In measuring the water content of the enzymes suspended in ethanol, $100-200 \mu$ l of the sample solution was then injected and the integral area of the water peak was compared with the standard.

\subsection{Active-Site Titration of Enzymes}

Active-site titration of the enzymes in phosphate buffer $(p \mathrm{H} \mathrm{8.2)}$ and in ethanol was performed at room temperature using $N$-tosyl-L-phenylalanine chloromethyl ketone (TPCK) as an inhibitor and Suc-Ala-Ala-Pro-Phe-pNA and Moz-Leu-OBzl as substrates, respectively. The substrate was added to a premixed solution of enzyme-inhibitor in phosphate buffer to make a final solution $(3 \mathrm{ml})$ containing substrate $(0.5 \mathrm{mM})$, enzyme $(0.25 \mathrm{mg})$, and inhibitor $(0.10-10.0 \mu \mathrm{M})$. The absorbance increment in a period of $10 \mathrm{~min}$ was measured spectrophotometrically at $407 \mathrm{~nm}$ and results plotted against the concentration of inhibitor. In transesterification, ethanol $(1.0 \mathrm{ml})$ containing MozLeu-OBzl $(25 \mathrm{mg})$ was added to a solution of premixed enzyme inhibitor $(1.0 \mathrm{ml})$ and the resulting mixture reacted for $30 \mathrm{~min}$. The formation of Moz-Leu-OEt was analyzed by HPLC (eluent: $\mathrm{CH}_{3} \mathrm{CN}: \mathrm{H}_{2} \mathrm{O}$ :TFA $=65: 35: 0.1$, a flow rate of $1 \mathrm{ml} / \mathrm{min}$, UV $254 \mathrm{~nm}$ ).

\subsection{Kinetics of Alcalase and Subtilisin Carlsberg}

The kinetic values of the alcalase-catalyzed reaction were determined by varying the substrate concentration and measuring the initial rates using HPLC. These initial rates were fitted to the Michaelis-Menten equation by using a nonlinear least-squares curve-fitting program. The concentration of substrates ranged from 0.005 to $0.050 \mathrm{M}$, 
and the amounts of alcalase were increased by $10-$, $100-$, or 1000 -fold.

\subsection{Stability of Alcalase and Subtilisin Carlsberg}

The stability of alcalase and subtilisin Carlsberg incubated in ethanol was determined by spectrophotometric measurement of absorbance increase at $410 \mathrm{~nm}$ due to the release of $p$-nitroanilide from the substrate Ala-Ala-Pro-PhepNA. In a typical reaction, $0.1 \mathrm{ml}$ of alcalase in $25 \mathrm{ml}$ of alcohol was stirred at $35^{\circ} \mathrm{C}$ to maintain a uniformly homogeneous state. Periodically, 50- $\mu 1$ aliquots were taken and added to a cuvette containing Ala-Ala-Pro-Phe-pNA $(10.0 \mu \mathrm{mol})$ in
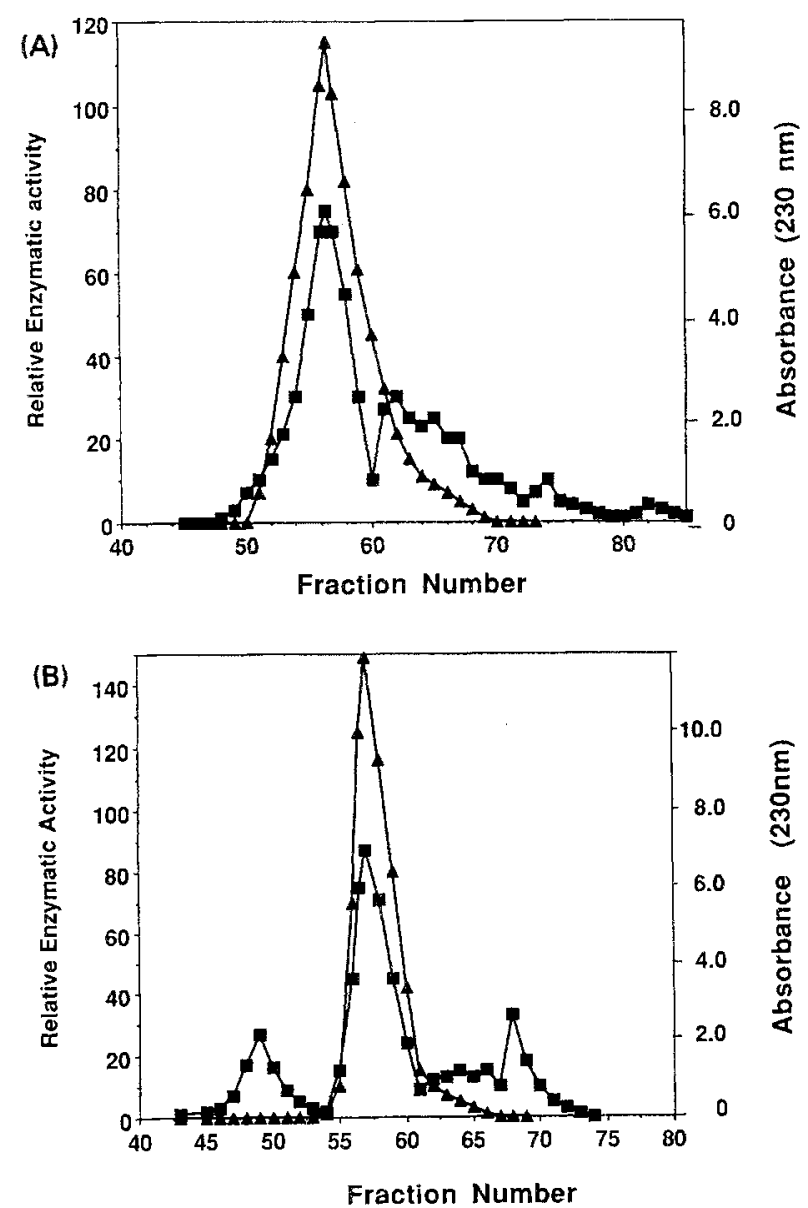

Fig. 1. Purification of subtilisin Carlsberg and alcalase by gel-filtration chromatography. The TSK HW-50 (S) gel was packed in a column $(2.7 \times 94 \mathrm{~cm})$ equilibrated in phosphate buffer $\left(p \mathrm{H} \mathrm{6.2)}\right.$ containing $1.0 \mathrm{mM}$ of $\mathrm{Ca}^{2+}$. The fractions $(5.1 \mathrm{ml} /$ tube per $6 \mathrm{~min}$ ) were collected and monitored for absorbance at $230 \mathrm{~nm}$ ( $\mathbf{m}$ ) and relative enzymatic activity in arbitrary units $(\mathbf{A})$ as described in Materials and Methods, Section 2. (A) Subtilisin Carlsberg; (B) alcalase.
$0.2 \mathrm{M}$ phosphate buffer. The initial rates of reaction were determined from time-dependent plots of the absorbance changes at $410 \mathrm{~nm}$ due to release of pNA. The activity measured at $10 \mathrm{sec}$ after the addition of alcalase to the alcoholic solution was taken to be $100 \%$ activity. Stability based on the transesterification activity of converting Moz-LeuOBzl to Moz-Leu-OEt in ethanol was assayed according to the procedures described above for transesterification analysis.

\subsection{Synthesis of Substrates}

Synthesis of tetrapeptide methyl esters as substrates for this study was essentially according to the previous report (Chen et al., 1993b). The physical data of melting points, optical rotation, amino acid analysis, and NMR spectral data to confirm the structures of these compounds were also included therein.

\section{RESULTS AND DISCUSSION}

\subsection{Purification of the Enzymes}

Purified alcalase was obtained via dialysis of the brown liquid $(2.5 \mathrm{AU} / \mathrm{ml})$ in phosphate buffer ( $p \mathrm{H}$ 6.0) containing $10 \mathrm{mM} \mathrm{Ca}^{2+}$ to remove the nutrition broth, precipitating enzymes by the addition of isopropanol, and eluting through a gel-filtration column using TSK HW-50 (S) gel. Commercial subtilisin Carlsberg (Sigma, Protease VIII, 11.6 units $/ \mathrm{mg}$ protein) was also purified to a homogeneous state via TSK HW-50 (S) gel filtration. Figure 1 shows the elution profiles of alcalase and subtilisin Carlsberg. The alcalase contained a small amount of denatured enzyme, and the commercial subtilisin Carlsberg contained low-molecular-weight peptides as revealed by gel electrophoresis (data not shown). The major fractions of chromatographed enzymes in both cases were collected and used directly.

\subsection{Preparation of Active Enzymes That Were Dissolved and Suspended in Ethanol}

Scheme 1 shows the procedure for the preparation of subtilisin Carlsberg and alcalase in soluble and dispersed forms from anhydrous ethanol. The freshly eluted enzyme from the above procedure was suspended in anhydrous ethanol by 


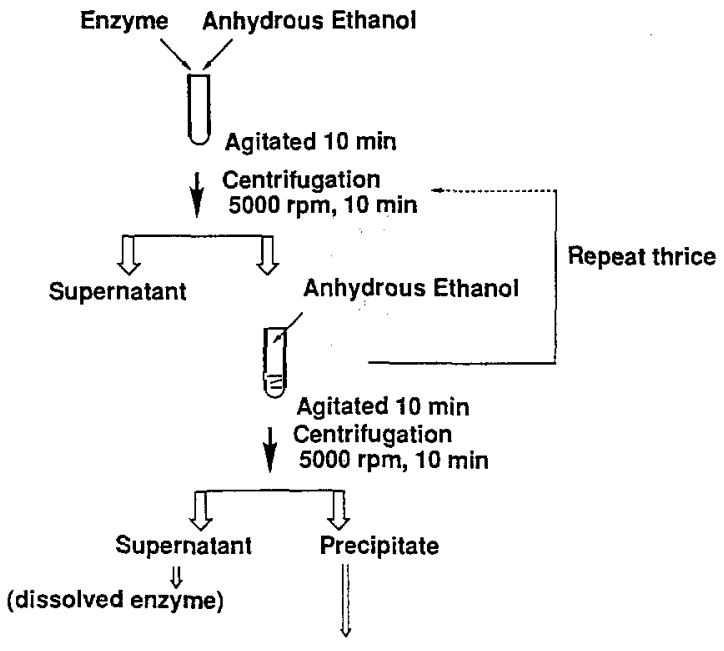

(suspended enzyme)

Scheme 1. Preparation of alcalase or subtilisin dissolved or suspended in ethanol.

agitation, the resulting mixture was centrifuged, and the supernatant was removed by decantation. The procedure was repeated three times. The precipitate was resuspended in ethanol and centrifuged. The supernatant of the fourth centrifuged solution and the suspension of precipitate were kept for the following study.

Figure $2 \mathrm{~A}$ shows the UV absorbance of the decanted alcoholic solution in five separate experiments. After the enzyme was processed three times, the absorbance values at $280 \mathrm{~nm}$ of the third supernatant were nearly the same and yet did not completely vanish. The higher absorbance background in the first and second supernatants could be due to the possibility that (1) the impurity dissolved in ethanol and was removed only after repeated precipitations or (2) the residual water content in the ethanolic solution after several alcohol extractions possessed high solubility for these enzymes. The same UV absorbance obtained after three washings would indicate that the solubility of the studied enzyme in anhydrous ethanol has reached a constant value. Using a Karl Fischer titration method, we also measured the water content of the dispersed enzyme in ethanol (see below). The water content of the enzyme in ethanol was found to be nearly constant after three precipitations.

\subsection{Solubility of Enzymes in Ethanol}

The solubility of the enzymes in anhydrous ethanol and in ethanol containing $1-10 \%$ of water

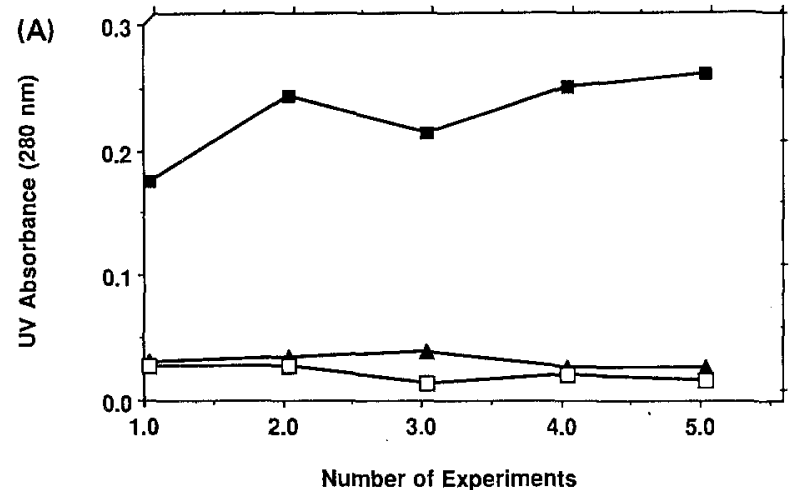

(B)

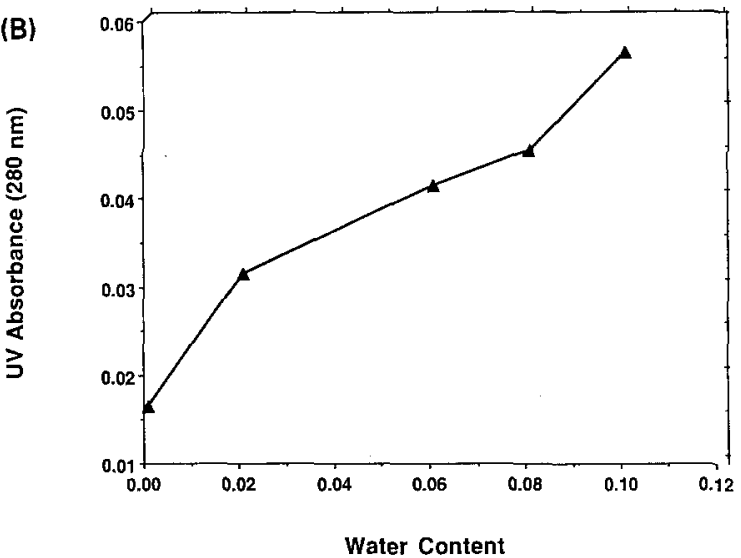

Fig. 2. Solubility of alcalase as measured by absorbance in the supernatants of alcohol solutions after multiple extractions with anhydrous ethanol. (A) Solubility study of alcalase for five separate experiments as measured by UV absorbance at $280 \mathrm{~nm}$ for the supernatants of $(\square)$ the first extraction, $(\Delta)$ the second extraction, and ( $\square$ ) the third extraction. (B) Solubility of alcalase as a function of water content. The enzyme in equal amounts was dissolved in ethanol containing $2-10 \%$ water and the UV absorbance at $280 \mathrm{~nm}$ was measured after low-speed centrifugation.

was measured by a Coomassie blue dye-binding method using BSA as calibration standard. The solubility of alcalase in absolute ethanol was $0.04807 \mathrm{mg} / \mathrm{ml}(1.76 \mu \mathrm{M})$ and that of subtilisin Carlsberg was $0.04511 \mathrm{mg} / \mathrm{ml}(1.69 \mu \mathrm{M})$ as determined by the dye-binding method. When the enzyme in ethanol was boiled for $10 \mathrm{~min}$, a white precipitate appeared. The supernatant of the boiled solution showed no enzymatic activity and no protein was detected by Coomassie blue dyebinding assay. Therefore denatured enzymes formed by heating were almost insoluble in a solution with a high alcohol content, i.e., in solvents of low water content.

In an ethanolic solution of varying water content $(2-10 \%)$, the solubility of enzymes 
increased with water content in ethanol as evidenced from UV absorbance of supernatants at $280 \mathrm{~nm}$ (Fig. 2B).

\subsection{Stability of the Dissolved and Suspended Enzymes in Ethanol}

The stability of the enzymes in ethanol was studied by measuring the amidase activity in buffer solution and the transesterase activity in anhydrous ethanol. Amidase activity were measured spectrophotometrically by the absorbance increase at $407 \mathrm{~nm}$ using N-Suc-Ala-Ala-Pro-Phe-pNA as a substrate. The transesterase activity was measured by the conversion of Moz-Leu-OBzl to Moz-LeuOEt in anhydrous ethanol and quantitated by the formation of Moz-Leu-OEt using HPLC. The stability of the enzyme in ethanol was estimated by
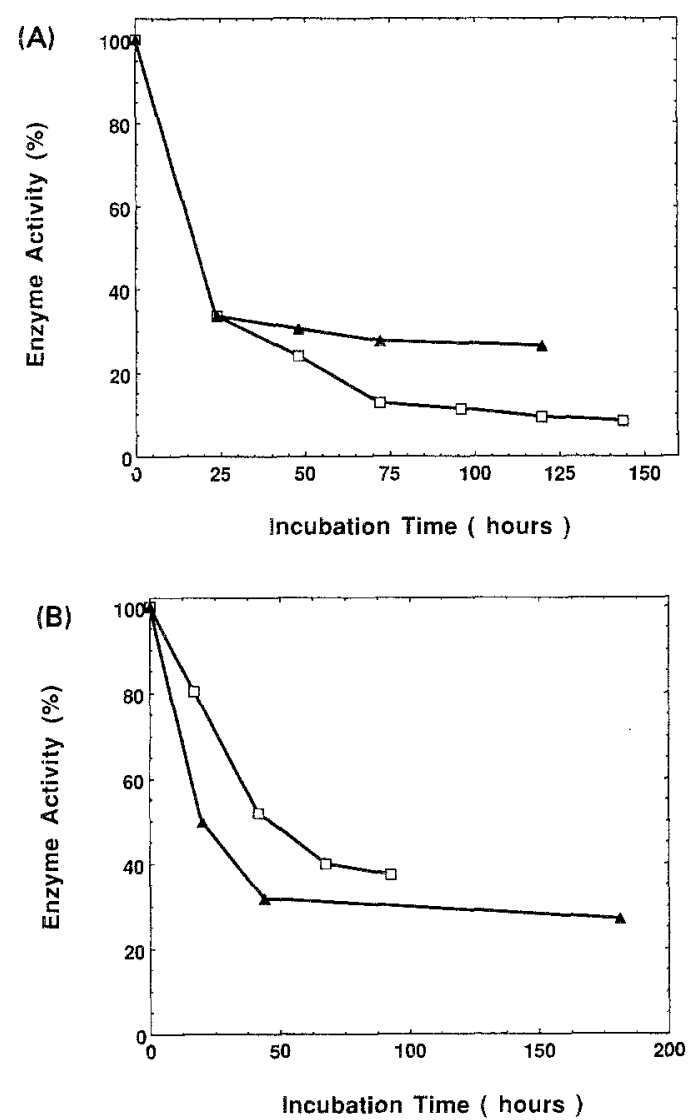

Fig. 3. Stability of enzymes as measured by the transesterase activity remaining after different periods of incubation. (A) The enzymes dissolved in anhydrous ethanol (the last supernatant fraction from Scheme 1) and (B) the suspended enzymes (the last precipitate fraction from Scheme 1) were assayed for transesterase activity as described in Materials and Methods, Section 2. (A) Subtilisin Carlsberg; ( $\square$ ) alcalase. the activities remaining after incubations of varied times.

Figures $3 \mathrm{~A}$ and $3 \mathrm{~B}$ show the residual transesterase activities of alcalase and subtilisin Carlsberg dissolved or suspended in ethanol. The dissolved alcalase and subtilisin Carlsberg maintained $37 \%$ activity for $24 \mathrm{hr}$ and still possessed higher than $10 \%$ activity for $150 \mathrm{hr}$. The suspended enzymes had a half-life of at least 20-30 hr and maintained at least $30 \%$ activity in ethanol for $150 \mathrm{hr}$. The dissolved subtilisin Carlsberg maintained higher activity than did the dissolved alcalase under the same incubation conditions. On the other hand, suspended alcalase possessed higher activity than did subtilisin Carlsberg under similar conditions. It is also noteworthy that the enzyme suspended in ethanol had a higher stability than the same enzyme dissolved in ethanol (compare Figs. $3 \mathrm{~A}$ and $3 \mathrm{~B})$.
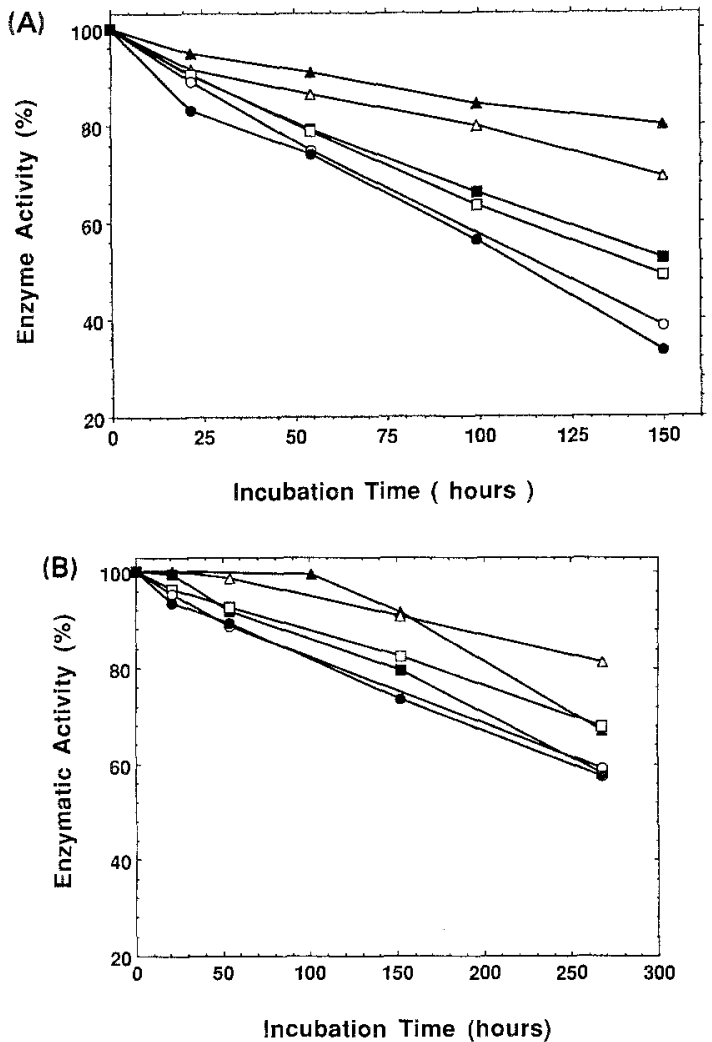

Fig. 4. Stability of dissolved and suspended alcalase as measured by the amidase activity remaining after different periods of incubation. (A) Dissolved and (B) suspended alcalase in ethanol was incubated in ethanol containing varied water contents for different periods and assayed for the amidase activity in aqueous

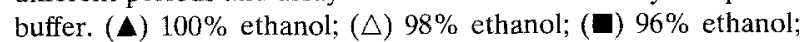
(ㄱ) $94 \%$ ethanol; (O) $92 \%$ ethanol; and (๑) $90 \%$ ethanol. 
Figures $4 \mathrm{~A}$ and $4 \mathrm{~B}$ show the amidase activities of alcalase remaining after incubation in ethanol containing varied percentages of water. It was found in general that the suspended enzyme (Fig. 4B) maintained higher stability than did the dissolved enzyme (Fig. 4A) in ethanol. The stability of alcalase decreased as the water concentration increased, and the dissolved enzyme lost amidase activity more drastically than did the suspended enzyme.

The subtilisin $\mathrm{BPN}^{\prime}$ was shown to lose its activity after lyophilization when the enzymatic activity was measured in organic solvents (Kise, 1990; Kise and Tomiuchi, 1991). On the other hand, the enzymatic activity recovered after dissolving the enzyme in aqueous buffer again and the enzymatic activity was measured in the buffer solution. In the case of our present investigation, the transesterase activity of the enzymes (compare Figs. 3A, 3B and Figs. 4A, 4B) decreased faster than did the amidase activity for the same incubation time. This may be due to the fact that the amidase activity was assayed in aqueous buffer solution, in which stripped water molecules in ethanol solvent can be regained by enzymes in the assay solution. During the process of transesterification assay in anhydrous ethanol, no water molecules were present in the assay medium. Thus the residual transesterase rather than amidase activity would be more realistic to represent the actual stability of the studied enzymes in nonaqueous solvents.

\subsection{Study of Active Sites of Subtilisin Carlsberg in Anhydrous Ethanol}

Several enzymes that are active in organic solvents have been reported (Klibanov, 1990). The reactivity of enzymes in organic solvents may differ from that in aqueous solution. However, methods for probing active sites of enzymes in high concentrations of organic solvents are very limited. Since alcalase and subtilisin Carlsberg can catalyze the transesterification in anhydrous ethanol, it would be feasible to study the active sites of these enzymes in anhydrous ethanol using conventional biochemical techniques. In order to get a meaningful and quantitative comparison of reactivity for these enzymes in organic solvents as compared with that in aqueous solution, a study of active-site titration for these enzymes by means of TPCK inhibitor in phosphate buffer $(p \mathrm{H} \mathrm{8.2)}$ and ethanol was performed at room temperature concurrently. Figures 5A and 5B show the typical titrations of active sites in subtilisin Carlsberg by TPCK in phosphate buffer and in ethanol. The subtilisin Carlsberg $(50 \mathrm{mg})$, dialyzed alcalase $(2.5 \mathrm{AU}, 1.0 \mathrm{ml})$, and purified alcalase $(2.5 \mathrm{AU}$, $1.0 \mathrm{ml}$ ) were used and suspended in ethanol $(1 \mathrm{~L})$ for these titration studies. The enzymes were incubated with varying concentrations of the inhibitor in buffer and ethanol for $4 \mathrm{hr}$ and the amidase and transesterase activities were then measured as described.

Table I shows the concentrations of active sites in the suspended enzymes as determined by TPCK, an active-site-specific inhibitor. The active-site concentration of subtilisin Carlsberg in aqueous solution was estimated to be $1.399 \times 10^{-6} \mathrm{M}$ and that of the same enzyme in ethanol was
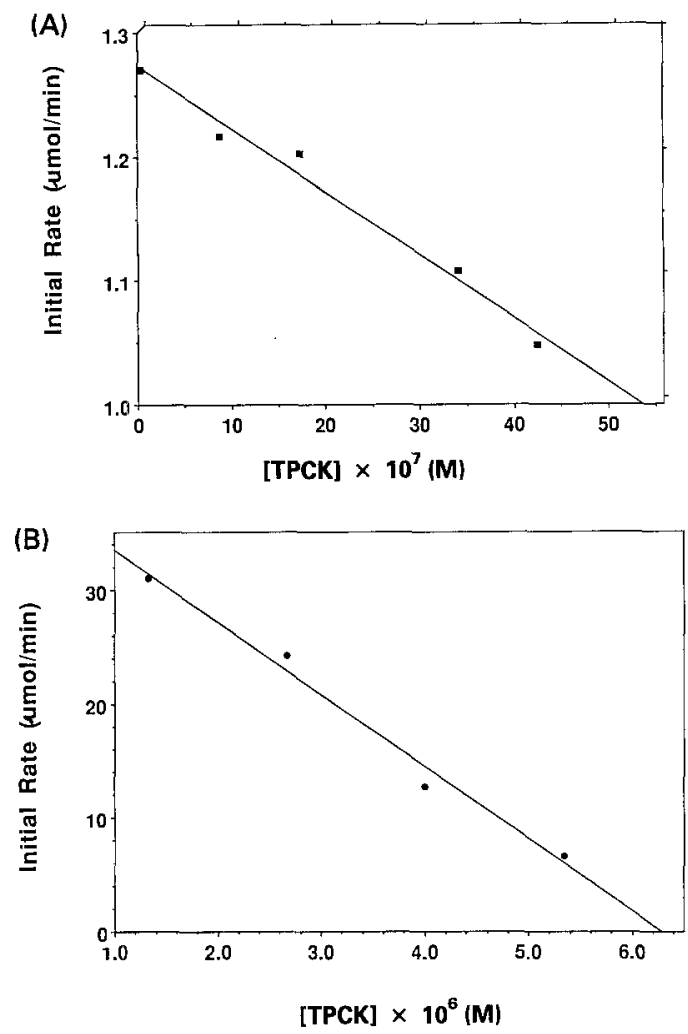

Fig. 5. Active-site titration of subtilisin Carlsberg for peptide hydrolysis in aqueous solution and transesterification in ethanol using TPCK, an irreversible serine protease inhibitor. Subtilisin Carlsberg $(50 \mathrm{mg})$ was suspended in ethanol $(1 \mathrm{~L})$ for these titration studies. The enzyme was incubated with varying concentrations of the inhibitor in buffer and ethanol for $4 \mathrm{hr}$ and the initial rates of enzyme reactions for (A) amidase in buffer and (B) transesterase in ethanol were then measured. The intercepts obtained at the $X$ axis represent the concentrations of active sites titrated by TPCK. 
Table I. Active-Site Titration of Subtilisin Carlsberg and Alcalase Measured in Ethanol and Phosphate Buffer Using TPCK as an Irreversible Inhibitor

\begin{tabular}{|c|c|c|}
\hline Enzyme & $\begin{array}{c}\text { Active } \\
\text { site } \\
\text { in } \\
\text { buffer } \\
\times 10^{6}(\mathrm{M})\end{array}$ & $\begin{array}{l}\text { Active } \\
\text { site } \\
\text { in } \\
\text { ethanol } \\
\times 10^{6}(\mathrm{M})\end{array}$ \\
\hline Subtilisin Carlsberg & 1.399 & 1.387 \\
\hline Alcalase & 5.962 & 5.930 \\
\hline Alcalase $^{a}$ & 6.069 & 4.871 \\
\hline
\end{tabular}

${ }^{a}$ The dialyzed alcalase was used without purification via gel filtration.

$1.387 \times 10^{-6} \mathrm{M}$. Since $50 \mathrm{mg}$ of subtilisin Carlsberg (mol. weight 27,240 ) in ethanol $(1 \mathrm{~L})$ is about $1.835 \times 10^{-6} \mathrm{M}$, the per cent active sites or percent of the active enzyme in water and ethanol relative to the original enzyme molecules would be $76.2 \%$ and $75.6 \%$, respectively. This suggested that subtilisin Carlsberg is as active enzymatically in ethanol as in buffer. As regards the titration of purified alcalase by TPCK, the active-site concentration was estimated to be $5.962 \times 10^{-6} \mathrm{M}$ and $5.930 \times 10^{-6} \mathrm{M}$ in buffer and ethanol, respectively, suggesting again that alcalase is also equally active in organic solvent. However, if the dialyzed alcalase was used without further purification, the titrated active-site concentration in aqueous solution was $6.069 \times 10^{-6} \mathrm{M}$ and that in ethanol was $4.871 \times$ $10^{-6} \mathrm{M}$. There is about $20 \%$ less active forms present in ethanol than in aqueous buffer. The reason for this anomaly arising from the alcalase sample is still unknown. There may still be some factors or impurities present in the preparation of dialyzed alcalase which somehow interfered with the titration of active sites by TPCK in ethanol.

\subsection{Amount of Water Bound to the Enzymes}

It is generally accepted that enzymes have a strong binding affinity for water molecules (Khmelnitsky et al., 1988; Klibanov, 1989). Bound water molecules can prevent enzymes from denaturation and also function as the bridge of a hydrogen-bond network required for enzymatic activity (Schultz and Schirmer, 1979). The crystal structure (McPhalen and James, 1988) of a complex of subtilisin Carlsberg and a genetically engineered $\mathrm{N}$-acetyl eglin-C showed clearly that there were 170 water molecules in the crystal lattices. Many reports have proposed that the preservation of enzyme activity in high concentration of organic solvents was due to an aqueous layer formed on the outer surface of the enzyme (Gupta, 1992). In order to test whether this proposal can be applied to the case of subtilisin Carlsberg suspended in anhydrous ethanol, we have measured the water content of the enzyme in anhydrous ethanol. The unremovable water that bound strongly with the enzyme in alcoholic solution can be measured by either a Fischer titrimetric method (Zaks and Klibanov, 1988) or gas chromatography (GC) (Reslow et al., 1988) using a thermoconductivity detector. The sensitivity of the Karl Fischer titration in determining water contents in organic solvents under our conditions was approximately $0.01 \%$ $(\mathrm{v} / \mathrm{v})$ and that of the GC method was approximately $0.001 \%$. Therefore the GC method with higher sensitivity was adopted more often in our analysis of water contents, especially for the precise determination of enzyme-bound water. By GC measurement, we found that the water concentration in the alcalase solution can be reduced to less than $0.01 \%$ by repeated washings with anhydrous alcohol and the water concentration remained constant after three washings of alcohol.

The subtilisin Carlsberg in ethanol, which was shown to contain $2.09 \times 10^{-6} \mathrm{~mol}$ of active sites by TPCK titration, was found to contain a water/ethanol ratio of $9.274 \times 10^{-4}(\mathrm{v} / \mathrm{v}$ in $10 \mathrm{ml}$ ethanol) by GC. This would indicate that there are about 246 water molecules per enzyme molecule. In the case of alcalase, 218 molecules of water were found. These water estimates for enzymes in ahydrous ethanol seemed to rule out the possibility that a water layer was formed around the enzyme surface to account for the enzyme activity in an organic solvent (compare with 170 water molecules determined in the crystal lattice of the complex of subtilisin Carlsberg and a genetically engineered $\mathrm{N}$-acetyl eglin-C reported before).

\subsection{Reactivity and Selectivity of the Enzyme- Catalyzed Reactions in Ethanol and in Aqueous Solution}

Selective hydrolysis catalyzed by alcalase and subtilisin Carlsberg in aqueous solution and transesterification in ethanol of two pairs of diastereo tetrapeptides, L-Ala-L-Ala-(D- or L-)Pro-LPhe-OMe and L-Ala-L-ALa-(D- or L-)Ala-L-PheOMe, were studied in order to compare the 
reactivity and selectivity of the enzyme-catalyzed reactions in two different media.

Table II shows the results of the kinetic study for the enzyme-catalyzed hydrolysis and transesterification. In aqueous solution, both enzymes hydrolyze the L-form tetrapeptide esters more efficiently than D-form peptide esters, with the specificity constants $\left(k_{\text {cat }} / K_{\mathrm{m}}\right)$ for L-epimers about 10 - to $10^{2}$-fold higher than those for $\mathrm{D}$-epimers. However, the diastereoselectivities of enzymes toward L- or D-epimers of peptide esters for the hydrolysis in aqueous buffer or transesterification in ethanol were very similar, as exemplified by the similar selectivity indices (the last column of Table II). Therefore it is concluded that the selectivity of alkaline serine proteases in anhydrous alcohol is very similar to that in aqueous solution in spite of the fact that a lower reactivity is usually associated with the enzymes in nonaqueous solvents.

\section{CONCLUSION AND PERSPECTIVES}

Enzyme catalysis in nonaqueous solvents has attracted a lot of attention recently due to its nonconventional approach and potential applications in bioorganic synthesis (Barbas and Wong, 1987; Laane, 1987; Arnold, 1988, 1990; Kitaguchi and Klibanov, 1989; Kuhl et al., 1990; Phillips et al., 1990; Wong et al., 1990; Wong and Wong, 1991; Zhong et al., 1991; Nagashimà et al., 1992). Enzymes of different sources, including alcalase, which can maintain their enzymatic activities to various extents in organic solvents have also been documented (Schulze and Klibanov, 1991). However, a protracted and important issue still remains regarding the exact role of organic media in the mechanism of enzyme catalysis as opposed to the commonly accepted enzymatic reactions in water or aqueous solution. Did the limited catalytic activity observed for enzymes in nonaqueous solvents reflect the same mechanistic aspects as that in water? There is always the suspicion that the observed activity is confined to those areas with residual hydrated layers present on the surfaces of enzyme molecules? This warrants the need for the precise and accurate determination of water content in high concentrations of organic solvent.

Khan et al. (1992) used a poly(ethylene glycol)-modified subtilisin Carlsberg as a form of microparticulate suspension in organic solvent to achieve enzyme catalysis in nonaqueous solvent. In this study we have circumvented the use of modified enzymes in the study of enzyme activity in systems of low water content by taking precautions

Table II. Kinetics of Peptide Ester Hydrolysis in Phosphate Buffer ( $p \mathrm{H} 8.2)$ and Transesterification in Ethanol by Alcalase and Subtilisin Carlsberg Using Tetrapeptide Methyl Esters as Substrates

\begin{tabular}{|c|c|c|c|c|c|c|}
\hline Substrate & Enzyme & Solvent & $\begin{array}{c}k_{\text {cat }} \\
(1 / \text { min })\end{array}$ & $\begin{array}{l}K_{\mathrm{m}} \\
(\mathrm{M})\end{array}$ & $k_{\text {cat }} / K_{\mathrm{m}}$ & $\begin{array}{l}\text { Select- } \\
\text { ivity }{ }^{a}\end{array}$ \\
\hline $\begin{array}{l}\text { Ala-Ala-Ala-Phe-OMe } \\
\text { Ala-Ala-D-Ala-Phe-OMe }\end{array}$ & $\begin{array}{l}\text { Alcalase } \\
\text { Alcalase }\end{array}$ & $\begin{array}{l}\text { Buffer } \\
\text { Buffer }\end{array}$ & $\begin{array}{c}1401.49 \\
17.18\end{array}$ & $\begin{array}{l}2.68 \times 10^{-3} \\
4.48 \times 10^{-3}\end{array}$ & $\begin{array}{l}5.23 \times 10^{5} \\
3.83 \times 10^{3}\end{array}$ & $1.37 \times 10^{2}$ \\
\hline $\begin{array}{l}\text { Ala-Ala-Ala-Phe-OMe } \\
\text { Ala-Ala-D-Ala-Phe-OMe }\end{array}$ & $\begin{array}{l}\text { Alcalase } \\
\text { Alcalase }\end{array}$ & $\begin{array}{l}\text { Ethanol } \\
\text { Ethanol }\end{array}$ & $\begin{array}{l}3.06 \times 10^{-6} \\
4.58 \times 10^{-8}\end{array}$ & $\begin{array}{l}1.45 \times 10^{-2} \\
1.15 \times 10^{-2}\end{array}$ & $\begin{array}{l}2.11 \times 10^{-4} \\
3.98 \times 10^{-6}\end{array}$ & $5.30 \times 10^{1}$ \\
\hline $\begin{array}{l}\text { Ala-Ala-Ala-Phe-OMe } \\
\text { Ala-Ala-D-Ala-Phe-OMe }\end{array}$ & $\begin{array}{l}\text { Subtilisin } \\
\text { Subtilisin }\end{array}$ & $\begin{array}{l}\text { Buffer } \\
\text { Buffer }\end{array}$ & $\begin{array}{l}3.58 \times 10^{4} \\
8.1 \times 10^{2}\end{array}$ & $\begin{array}{l}1.54 \times 10^{-3} \\
2.58 \times 10^{-3}\end{array}$ & $\begin{array}{l}2.32 \times 10^{7} \\
3.14 \times 10^{5}\end{array}$ & $7.39 \times 10^{1}$ \\
\hline $\begin{array}{l}\text { Ala-Ala-Ala-Phe-OMe } \\
\text { Ala-Ala-D-Ala-Phe-OMe }\end{array}$ & $\begin{array}{l}\text { Subtilisin } \\
\text { Subtilisin }\end{array}$ & $\begin{array}{l}\text { Ethanol } \\
\text { Ethanol }\end{array}$ & $\begin{array}{l}135.9 \\
5.867\end{array}$ & $\begin{array}{l}1.23 \times 10^{-2} \\
7.36 \times 10^{-3}\end{array}$ & $\begin{array}{l}1.10 \times 10^{4} \\
7.97 \times 10^{2}\end{array}$ & $1.38 \times 10^{1}$ \\
\hline $\begin{array}{l}\text { Ala-Ala-Pro-Phe-OMe } \\
\text { Ala-Ala-D-Pro-Phe-OMe }\end{array}$ & $\begin{array}{l}\text { Alcalase } \\
\text { Alcalase }\end{array}$ & $\begin{array}{l}\text { Buffer } \\
\text { Buffer }\end{array}$ & $\begin{array}{c}103.21 \\
0.825\end{array}$ & $\begin{array}{l}8.63 \times 10^{-3} \\
2.37 \times 10^{-2}\end{array}$ & $\begin{array}{c}1.20 \times 10^{4} \\
34.8\end{array}$ & $3.45 \times 10^{2}$ \\
\hline $\begin{array}{l}\text { Ala-Ala-Pro-Phe-OMe } \\
\text { Ala-Ala-D-Pro-Phe-OMe }\end{array}$ & $\begin{array}{l}\text { Alcalase } \\
\text { Alcalase }\end{array}$ & $\begin{array}{l}\text { Ethanol } \\
\text { Ethanol }\end{array}$ & $\begin{array}{l}6.56 \times 10^{-7} \\
7.50 \times 10^{-8}\end{array}$ & $\begin{array}{c}1.15 \times 10^{-2} \\
0.197\end{array}$ & $\begin{array}{l}5.70 \times 10^{-5} \\
3.81 \times 10^{-7}\end{array}$ & $1.50 \times 10^{2}$ \\
\hline $\begin{array}{l}\text { Ala-Ala-Pro-Phe-OMe } \\
\text { Ala-Ala-D-Pro-Phe-OMe }\end{array}$ & $\begin{array}{l}\text { Subtilisin } \\
\text { Subtilisin }\end{array}$ & $\begin{array}{l}\text { Buffer } \\
\text { Buffer }\end{array}$ & $\begin{array}{l}4.05 \times 10^{4} \\
1.36 \times 10^{3}\end{array}$ & $\begin{array}{l}5.83 \times 10^{-3} \\
3.43 \times 10^{-2}\end{array}$ & $\begin{array}{l}6.95 \times 10^{6} \\
3.97 \times 10^{4}\end{array}$ & $1.75 \times 10^{2}$ \\
\hline $\begin{array}{l}\text { Ala-Ala-Pro-Phe-OMe } \\
\text { Ala-Ala-D-Pro-Phe-OMe }\end{array}$ & $\begin{array}{l}\text { Subtilisin } \\
\text { Subtilisin }\end{array}$ & $\begin{array}{l}\text { Ethanol } \\
\text { Ethanol }\end{array}$ & $\begin{array}{c}50.947 \\
0.378\end{array}$ & $\begin{array}{l}1.06 \times 10^{-2} \\
6.73 \times 10^{-3}\end{array}$ & $\begin{array}{c}4.81 \times 10^{3} \\
56.2\end{array}$ & $8.56 \times 10^{1}$ \\
\hline
\end{tabular}

${ }^{a}$ Selectivity indices are calculated from the ratios of $k_{\text {cat }} / K_{\mathrm{m}}$ for the hydrolysis of diastereopeptide esters in buffer or the transesterification of their esters in ethanol [i.e., the ratio of (L-L-L-L)/(L-L-D-L)]. 
to strip as much as possible all residual water molecules from enzymes in organic media in order to exclude the role of the water layer for enzyme catalysis in nonaqueous solvents (Zaks and Klibanov, 1988; Affleck et al., 1992). The solubilities of alcalase and subtilisin Carlsberg in anhydrous alcohol have also been determined with accuracy. The study revealed for the first time that these two enzymes indeed possessed a limited solubility of about $40-50 \mu \mathrm{g} / \mathrm{ml}$ in anhydrous alcohol. The subtilisin Carlsberg and alcalase in ethanol were also shown to contain about 246 and 218 water molecules per enzyme molecule by combining active-site titration with site-specific TPCK inhibitor and water determination by GC. The estimate of these enzyme-bound water molecules seemed to be too low to account for the formation of a hydration layer around the enzymes when compared with those water molecules found in the crystal lattice of subtilisin (McPhalen and James, 1988; Bott et al., 1988).

We previously found that the circular dichroic spectrum of alcalase dissolved in ethanol was similar to that of the enzyme in buffer (Chen et al., 1993a), which was in accord with that reported by Merutka et al. (1991) on the spectra of subtilisin Carlsberg in organic solvent and aqueous buffer. A recent report (Fitzpatrick et al, 1993) on the crystal structure of subtilisin Carlsberg in anhydrous acetonitrile indicated that the three-dimensional structure of this enzyme in this anhydrous solvent is essentially similar to that in water, which corroborated our previous results on circular dichroism and the current estimation of active-site concentration by TPCK titration. Therefore the gross and local conformations plus the accessibility of active sites of subtilisin Carlsberg and alcalase in alcohol and aqueous buffer seem to be well conserved upon change of solvent media. The reactivities and high diastereoselectivity of both enzymes observed in anhydrous alcohol are similar to those found in aqueous solution. This study and our earlier reports (Chen et al., 1991a,b, 1992a,b; $1993 a, b)$ clearly demonstrated that the hydrolysis and transesterification reactions catalyzed by alcalase and subtilisin Carlsberg in anhydrous alcohol are genuine and possess similar characteristics to those in aqueous solution or in $95 \%$ $t$-butanol containing $5 \%$ buffer (Chen et al., 1991a). They also reveal that enzymes in organic solvents always result in enhanced thermal stability as compared with those in aqueous solution and the mechanistic features for catalysis may also be maintained without major álteration. It should prove feasible to engineer enzymes isolated from natural sources based on knowledge gained from the study of these enzymes in organic solvents.

\section{ACKNOWLEDGMENTS}

Support for this research provided by the National Science Council, Taipei, TAIWAN (Grants NSC 81-0208-N-001-70, NSC 82-0115-C-001$078 \mathrm{M}$, NSC 83-0418-B-001-017BA, and NSC 83-0418-B-001-020BA) is gratefully acknowledged.

\section{REFERENCES}

Affleck, R., Xu, Z. F., Suzawa, V., Focht, K., Clark, D. S., and Dordick, J. S. (1992). Proc. Natl. Acad. Sci. USA 89, 1100-1104.

Arnold, F. H. (1988). Protein Eng. 2, 21-25.

Arnold, F. H. (1990). Trends Biotechnol. 8, 224-249.

Barbas, III, C. F., and Wong, C. H. (1987). J. Chem. Soc. Chem. Commun. 1987, 532-534.

Bott, R., Ultsch, M., Kossiakoff, A., Graycar, T., Katz, B., and Power, S. (1988). J. Biol. Chem. 263, 7895-7906.

Brink, L. E. S., Tramper, J., Luyben, K. Ch. A. M., and Riet, K. V. (1988). Enzyme Microb. Technol. 10, 736-743.

Chen, S.-T., Chen, S.-Y., Hsiao, S.-C., and Wang, K.-T. (1991a). Biotech. Lett. 13, 773-778.

Chen, S.-T., Hsiao, S.-C., and Wang, K.-T. (1991b). Bioorg. Med. Chem. Lett. 1, 445-450.

Chen, S.-T., Chen, S.-Y., and Wang, K.-T. (1992a). J. Org. Chem. 57, 6960-6965.

Chen, S.-T., Hsiao, S.-C., Chiou, A.-J., Wu, S.-H., and Wang, K.-T. (1992b). J. Chin. Chem. Soc. 39, 91-99.

Chen, S.-T., Chen, S.-Y., Tu, C.-C., and Wang, K.-T. (1993a). Bioorg. Med. Chem. Lett. 3, 1643-1648.

Chen, S.-T., Tu, C.-C., Chen, S.-Y., Huang, H.-C., and Wang, K.-T. (1993b). Bioorg. Med. Chem. 1, 361-367.

Dordick, J. S. (1992). Biotechnol. Prog. 8, 259-267.

Erp, S. H. M. V., Kamenskaya, E. O., and Khmelnitsky, Y. L. (1991). Eur. J. Biochem. 202, 379-384.

Fitzpatrick, P. A., and Klibanov, A. M. (1991). J. Am. Chem. Soc. 113, 3166-3171.

Fitzpatrick. P. A., Steinmetz, A. C. U., Ringe, D., and Klibanov, A. M. (1993). Proc. Natl. Acad. Sci. USA 90, 8653-8657.

Gill, I., and Vulfson, E. N. (1993). J. Am. Chem. Soc. 115, $3348-3349$.

Gupta, M. N. (1992). Eur. J. Biochem. 203, 25-32.

Khan, S. A., Halling, P. J., Bosley, J. A., Clark, A. H., Peilow, A. D., Pelan, E. G., and Rowlands, D. W. (1992). Enzyme. Microb. Technol. 14, 96-100.

Khmelnitsky, Y. L., Levashov, A. V., Klyachko, N. L., and Martinek, K. (1988). Enzyme Microb. Technol. 10, 709-724. Kise, H. (1990). Bioorg. Chem. 18, 107-115.

Kise, H., and Tomiuchi, Y. (1991). Biotech. Lett. 13, 317-322.

Kitaguchi, H., and Klibanov, A. M. (1989). J. Am. Chem. Soc. 111, $9272-9273$.

Klibanov, A. M. (1986). Chemtech 16, 354-359.

Klibanov, A. M. (1989). Trends Biochem. Soc. 14, 141-144.

Klibanov, A. M. (1990). Acc. Chem. Res. 23, 114-120.

Kuhl, P., Halling, P. J., and Jakubke, H. D. (1990). Tetrahedron Lett. 31, 5213-5216. 
Laane, C. (1987). Biocatalysis 1, 17-22.

Margolin, A. L., Tai, D. F., and Klibanov, A. M. (1987). J. Am. Chem. Soc. 109, 7885-7887.

Matsushima, A., Okada, M., and Inada, Y. (1994). FEBS Lett. 178, 275-277.

McPhalen, C. A., and James, M. N. G. (1988). Biochemistry 27, 6582-6598.

Merutka, G., Shalongo, W., and Stellwagen, E. (1991). Biochemistry 30, 4245-4248.

Nagashima, T., Watanabe, A., and Kise, H. (1992). Enzyme Microb. Technol. 14, 842-847.

Philipp, M., and Bender, M. L. (1983). Mol. Cell. Biochem. 51, 5-32.

Phillips, R. S., Matthews, M. S., Olson, E., and Tersch, R. L. V. (1990). Enzyme Microb. Technol. 12, 731-735.

Reslow, M., Adlercreutz, P., and Mattiasson, B. (1988). Eur. J. Biochem. 172, 573-578.

Ricca, J. M., and Crout, D. H. G. (1989). J. Chem. Soc. Chem. Commun. 1989, 2126-2127.

Riva, S., Chopineau, J., Kieboom, A. P. G., and Klibanov, A. M. (1988). J. Am Chem. Soc. 110, 584-589.

Sakurai, T., Margolin, A. L., Russell, A. J., and Klibanov, A. M. (1988). J. Am. Chem. Soc. 110, 7236-7237.
Schellenberger, V., and Jakubke, H. D. (1991). Angew. Chem. Int. Ed. Engl. 30, 1437-1449.

Schultz, G. E., and Schirmer, R. H. (1979). In Principles of Protein Structure, Springer, New York.

Schulze, B., and Klibanov, A. M. (1991). Biotech. Bioeng. 38, 1001-1006.

Stahl, M., Mansson, M. O., and Mosbach, K. (1990). Biotech. Lett. 12, 161-166.

Waks, M. (1986). Proteins Struct. Funct. Genet., 1, 4-15.

Wells, J. A., and Estell, D. A. (1988). Trends Biochem. Sci. 13, 291-294.

West, J. B., and Wong, C. H. (1986). J. Chem. Soc. Chem. Commun. 1986, 417-418.

Wong, C. H., Chen, S. T., Hennen, W. J., Bibbs, J. A., Wang, Y. F., Liu, J. L. C., Pantoliano, M. W., Whitlow, M., and Bryan, P. N. (1990). J. Am. Chem. Soc. 112, 945-953.

Wong, C. H., and Wang, K. T. (1991). Experientia 47, 1123 1129.

Zaks, A., and Klibanov, A. M. (1988). J. Biol. Chem. 263, 3194-3201.

Zhong, Z., Liu, J. J. C., Dinterman, L. M., Finkelman, M. A. J., Mueller, T. W., Rollence, M. L., Whitlow, M., and Wong, C. H. (1991). J. Am. Chem. Soc. 113, 683-684. 